\title{
Efektivitas Problem Focused Coping Dalam Mengatasi Stress Belajar Siswa Pada Pelajaran Matematika
}

\author{
Idriani Idris \\ Bimbingan dan Konseling, Universitas Negeri Makassar \\ email: idriani_ck09@yahoo.co.id \\ Abdulah Pandang \\ Bimbingan dan Konseling, PPs Universitas Negeri Makassar \\ email: abdullahpandang@gmail.com
}

(Diterima: 10-April-2018; di revisi:14-Mei-2018; dipublikasikan: 27-Juni-2018)

\begin{abstract}
The main problem examined in this research is students' learning stress in Mathematics subject using Problem Focused Coping technique. The research aims at discovering (i) the degree of students' learning stress in Mathematics subject before and after implementing Problem Focused Coping technique, (ii) the effectiveness of Problem Focused Coping technique in solving students' learning stress in Mathematics subject. The populations and samples of the research were class VIII students at SMPN 1 North Galesong of academic year 2015/2016 who were identified to experience stress in Mathematics subject with the total samples 38 students, consisted of 19 students were in the control group and 19 students were in the experiment group. The instruments used were questionnaire and observation. The data of the research were analyzed by using descriptive analysis and inferential statistics analysis with ttest. The result of the research reveal that (i) the degree of the students' learning stress in Mathematics subject before implementing Problem Focused Coping technique is in high category; then, the students' learning stress decreases after implementing Problem Focused Coping technique, which is in medium category, (ii) the Problem Focused Coping technique is effective in solving the students' learning stress in Mathematics subject.
\end{abstract}

Keywords : Stress Learning, Problem Focused Coping

Abstrak: Permasalahan Pokok yang dikaji dalam penelitian ini yaitu stress belajar siswa pada mata pelajaran matematika dengan Teknik Problem Focused Coping. Tujuan penelitian ini (i) Mengetahui tingkat stress belajar siswa pada pelajaran matematika sebelum dan sesudah diberikan Teknik Problem Focused Coping. (ii) Mengetahui efektifitas Teknik Problem Focused Coping dalam mengatasi stress belajar siswa pada pelajaran matematika. Pendekatan penelitian yang digunakan adalah kuantitatif dengan desain true experimental, pretest-posttest control group design. Populasi dan sampel penelitian ini adalah siswa kelas VIII SMP Negeri I Galut yang teridentifikasi mengalami stress belajar pada pelajaran matematika dengan jumlah sampel penelitian sebanyak 38 orang, 19 orang kelompok kontrol dan 19 orang kelompok eksperimen. Instrumen yang digunakan adalah skala dan observasi. Analisis data yang digunakan adalah analisis deskriptif, dan analisis statistik inferensial dengan t-test. Hasil penelitian menunjukkan bahwa: (i) Tingkat stres belajar siswa pada pelajaran matematika sebelum diberikan teknik Problem Focused Coping berada pada kategori tinggi kemudian mengalami penurunan setelah diberikan teknik Problem Focused Coping yaitu berada pada ketegori sedang. (ii) Teknik Problem Focused Coping efektif dalam mengatasi stres belajar siswa pada pelajaran matematika.

Kata kunci: Stress Belajar, Problem Focused Coping. 


\section{PENDAHULUAN}

Matematika merupakan salah satu disiplin ilmu yang telah berkmbang pesat di semua Negara termasuk Indonesia. Hudoyono (Nawangsari, 2000), berpendapat bahwa pemfokusan pelajaran matematika disebabkan matematika merupakan dasar untuk mengembangkan ilmu, sehingga diperlukan tenaga yang terampil untuk meperoleh generasi yang berkualitas di masa yang akan datang. Namun perkembangan ilmu matematika tidak sesuai dengan yang diharapkan. Terlihat dari, masih banyaknya siswa yang menganggap pelajaran matematika sebagai pelajaran yang rumit, menakutkan, penuh dengan lambanglambang serta rumus-rumus yang sulit serta membutuhkan konsentrasi yang tinggi untuk dapat mengerti pelajaran matematika. Anggapan-anggapan tersebut yang menyebabkan minat belajar siswa pada pelajaran matematika cenderung menurung dan tidak sedikit yang mengganggap pelajaran matematika adalah pelajaran yang membuat stress.

Stress belajar yang dialami para siswa dapat menimbulkan beberapa dampak. Wulandari (2012), mengemukakan stress belajar dapat menimbulkan dampak secara jangka pendek diantaranya adalah respon secara psikologis seperti sulit konsentrasi, takut, dan putus asa, sedangkan respon fisik timbul serangan sakit perut, sakit kepala, serta respon secara perilaku yang ditunjukkan dengan gemetar, gagap, dan keinginan melakukan tindakan agresif kepada orang lain. Adapun dampak jangka panjangnya yaitu menurunnya daya tahan tubuh, depresi, dan mulai mengkonsumsi rokok dan minum-minuman keras. Stress memiliki makna yang berbeda dan mempunyai akibat yang berbeda pula pada setiap siswa.

Rickard (2000), mengemukakan bahwa stress merupakan suatu motivasi yang dibutuhkan oleh individu untuk bergerak dan merupak suatu energy yang dapat digunakan secara efektif. Hal ini sejalan dengan pendapat Prawitasari (1988) bahwa stress yang dosisnya kecil merupakan tantangan dan motivasi bagi seseorang untuk bergerak ke arah yang lebih baik, tetapi stress yang terlalu berat akan menjadi sesuatu yang menganggu kestabilan diri individu dan akan membawa penderitaan sehingga berdampak pada kesehatan dan prestasi akademis.
Berdasarkan hasil studi pendahuluan melalui skala yang telah disebarkan pada kelas VIII di SMP Negeri 1 Galesong Utara dan wawancara dengan guru mata pelajaran serta guru BK, menunjukkan terdapat 101 siswa kelas VIII yang mengalami stress belajar matematika dengan tingkatan yang berbeda-beda. Adapun gejala stres belajar pada pelajaran matematika yang ditunjukkan siswa antara lain: merasa tegang ketika mengikuti pelajaran matematika, bahkan ketika diminta maju didepan kelas dia merasakan khawatir yang berlebihan, berkeringat dingin, dan wajahnya pucat, keluar masuk kelas, membolos saat jam pelajaran matematika, dan melamun bahkan siswa juga tidak mengerjakan tugas sekolah yang diberikan oleh gurunya.

Stress belajar siswa pada pelajaran matematika merupakan salah satu wujud masalah akademik siswa yang tentunya merupakan bidang kajian bimbingan dan konseling untuk bisa mereduksinya. Melihat fenomena yang terjadi pada siswa bahwa stress belajar siswa pada mata pelajaran matematika lebih banyak mengarah pada kognisinya maka salah satu cara yang dianggap peneliti dapat mengatasi stres belajar siswa adalah Problem Focused Coping.

Taylor (2007), mengemukakan problem focused coping merupakan suatu tindakan yang berupa respon tingkah laku dan pikiran individu untuk mengatur, meminimalkan, atau menguasai tuntutan-tuntutan dari dalam dan dari luar yang melebihi batas-batas kemampuannya.

Pada coping terpusat masalah ini, bentuk tingkah lakunya berupa upaya untuk mengontrol situasi yang tidak menyenangkan dan memecahkan permasalahan. Sementara bentuk kognitif dari jenis coping ini adalah upaya yang ditujukan untuk mengubah cara untuk mempersepsikan dan menginterprestasi situasi (Taylor, 2007). Sedangkan Lazarus (2006), mengemukakan problem focused coping yaitu individu bereaksi dalam menghadapi masalah dengan cara berusaha mencari penyebab masalah dan berusaha menyelesaiakan dengan beberapa alternative pemecahan masalah dengan mempelajari cara-cara atau ketrampilanketrampilan yang baru. Adapun strategi dalam problem focused coping terdiri dari lima yaitu active coping, suppersion of competing activities, restraining coping, turning to religion, dan planning.

Tujuan dalam penelitian ini yaitu untuk mengetahui tingkat stress belajar siswa pada 
pelajaran matematika sebelum dan sesudah diberikan teknik problem focused coping. Serta, menguji efektifitas teknik problem focused coping dalam mengatasi stress belajar siswa pada mata pelajaran matematika di SMP Negeri 1 Galesong Utara. Adapun hipotesis dalam penelitian ini yaitu "problem focused coping efektif dalam mengatasi stress belajar siswa

Tabel 3.1 Model Desain Eksperimen pada pelajaran matematika di SMP Negeri 1 Galesong Utara Kab. Takalar.

\section{METODE}

Pendekatan dalam penelitian ini adalah pendekatan penelitian kuantitatif, Jenis penelitian yang digunakan adalah true experimental yaitu Pretest-Posttest Control Group Design.

\begin{tabular}{llccc}
\hline & Group & Pretest & Variabel & $\begin{array}{c}\text { Post } \\
\text { test }\end{array}$ \\
\hline $\mathrm{R}$ & Eksperimen & $\mathrm{O} 1$ & $\mathrm{X}$ & $\mathrm{O} 2$ \\
$\mathrm{R}$ & Kontrol & $\mathrm{O} 3$ & - & $\mathrm{O} 4$ \\
\hline
\end{tabular}

(Sugiyono, 2012:114)

Dalam penelitian ini mengkaji dua variabel yaitu, Efektivitas Teknik Problem Focused Coping (X) dan Stress Belajar Siswa Pada Mata Pelajaran Matematika (Y).

Problem focused coping (X) adalah teknik pemberian bantuan dimana reaksi individu dalam menghadapi masalah berusaha menyelesaikannya dengan beberapa alternatif pemecahan masalah yang dilakukan melalui beberapa strategi 1) Active Coping. 2) Suppersion of Competing Activities, 3) Restraining Coping, 4) Turning to Religion 5) Planning. Sedangkan Stres belajar matematika (Y) adalah adanya suatu stimulus yang tidak sesuai dengan diri individu dengan respon psikologis, fisiologis, dan sosial yang dialami oleh individu.

Penelitian ini dilaksanakan di SMP Negeri 1 Galesong Utara Kab. Takalar. dengan jumlah populasi 101 siswa yang teridentifikasi mengalami stress belajar matematika dengan menarik sampel penelitian secara random sampling sebanyak 38 orang yang dibagi menjadi dua kelompok, 18 orang kelompok ekperimen dan 18 orang kelompok control.

Teknik pengumpulan data yang digunakan dalam penelitian ini adalah skala dan observasi. Data-data yang diperoleh melalui skala stress belajar matematika yang dibuat sendiri oleh peneliti dimana sebelum dipakai dalam penelitian diuji validitas terlebiih dahulu oleh dua ahli yang berkompeten dalam bidang psikologi dan bimbingan dan konseling selanjutnya diuji lapangan terbatas untuk mengetahui validitas dan realibilitasnya.

Teknik analisis data yang digunakan untuk mengolah data adalah analisis statistik deskriptif, analisis statistik inferensial serta $t$-test menggunakan SPSS 20.

\section{HASIL DAN PEMBAHASAN}

Berdasarkan hasil penelitian yang dilaksanakan di SMP Negeri 1 Galesong Utara Kab. Takalar terhadap 38 orang siswa guna mengetahui stress belajar siswa pada pelajaran matematika sebelum dan sesudah diberikan teknik problem focused coping.

Pelaksanaan teknik problem focused coping yang diberikan kepada kelompok eksperimen mulai dari pretest, pemberian teknik problem focused coping sampai posttest berlangsung selama 7 kali pertemuan.

Adapun analisis statistic deskriptif gambaran tingkat stress siswa pada pelajaran matematika baik kelompok eksperimen maupun kelompok kontrol dari hasil pretest dan posttest sebagai berikut. 
Tabel 4.1 Data tingkat stress belajar siswa pada pelajaran matematika kelompok eksperimen sebelum (pretest) dan setelah (posttest) diberi teknik Problem focused coping

\begin{tabular}{clcccc}
\hline & & \multicolumn{4}{c}{ Kelompok Eksperimen } \\
\cline { 3 - 6 } Interval & \multirow{2}{*}{ Kategori } & \multicolumn{3}{c}{ Pretest } & \multicolumn{2}{c}{ Posttest } \\
\cline { 3 - 6 } & & Frekuensi & Persentase & Frekuens & Persentase \\
& & 3 & $15,7 \%$ & 0 & $0 \%$ \\
$143-167$ & Sangat Tinggi & 9 & $47,3 \%$ & 3 & $15,7 \%$ \\
$118-142$ & Tinggi & 7 & $37 \%$ & 6 & $31,6 \%$ \\
$93-117$ & Sedang & 0 & $0 \%$ & 7 & $37 \%$ \\
$68-92$ & Rendah & 0 & $0 \%$ & 3 & $15,7 \%$ \\
$42-67$ & Sangat Rendah & $\mathbf{1 9}$ & $\mathbf{1 0 0 \%}$ & $\mathbf{1 9}$ & $\mathbf{1 0 0 \%}$ \\
& Jumlah & & &
\end{tabular}

Sumber: Hasil Angket Kelompok Eksperimen

Tingkat stress belajar siswa pada pelajaran matematika di SMP Negeri 1 Galesong Utara Kab. Takalar sebelum diberi teknik problem focused coping untuk kelompok eksperimen, berada dalam ketegori sangat tinggi sebanyak 3 responden $(15,7 \%)$, kemudian kategori tinggi sebanyak 9 responden $(47,3 \%)$, sedangkan pada ketegori sedang sebanyak 7 responden (37\%), dan tidak ada siswa yang berada pada ketegori rendah dan sangat rendah. Selanjutnya sesuai dengan nilai rata-rata skor yang diperoleh sebesar 121,3, dimana nilai rata-rata tersebut berada pada interval 118-142 yang berarti tinggi. Hal ini menunjukkan bahwa tingkat stress belajar siswa pada pelajaran matematika di SMP Negeri 1 Galesong Utara Kab. Takalar berada dalam ketegori tinggi.

Setelah diberi teknik problem focused coping, tingkat stress belajar siswa pada pelajaran matematika mengalami penurunan. Hal ini dapat dilihat dari tingkat stress belajar siswa pada pelajaran matematika yang berada pada ketegori tinggi sebanyak 3 responden $(15,7 \%)$, kategori sedang sebanyak 6 responden $(31,6 \%)$, disusul kategori rendah sebanyak 7 responden (37\%), dan sangat rendah 3 responden $(15,7 \%)$. Selanjutnya sesuai dengan nilai rata-rata skor yang diperoleh sebesar 93,3, dimana nilai rata-rata tersebut berada pada interval 93-117 yang berarti sedang. Hal ini menunjukkan bahwa tingkat stress belajar siswa pada pelajaran matematika di SMP Negeri 1 Galesong Utara Kab. Takalar mengalami penurunan atau berada pada ketegori sedang. Perubahan-perubahan tersebut terjadi dikarenakan siswa telah diberikan teknik problem focused coping yang terdiri dari 7 sesi pertemuan.

Selama pemberian teknik problem focused coping peneliti juga melakukan observasi. Hasil observasi tersebut dapat dilihat pada tabel berikut:

Tabel 4.2 Data hasil analisis persentase Observasi Pelaksanaan Teknik Problem focused coping.

\begin{tabular}{|c|c|c|c|c|c|c|}
\hline \multirow{2}{*}{ Persentase } & \multirow{2}{*}{ Kriteria } & \multicolumn{5}{|c|}{ Pertemuan } \\
\hline & & I & II & III & IV & $\mathbf{V}$ \\
\hline $80 \%-100 \%$ & Sangat Tinggi & 0 & 0 & 3 & 6 & 17 \\
\hline $60 \%-79 \%$ & Tinggi & 2 & 4 & 10 & 12 & 2 \\
\hline $40 \%-59 \%$ & Sedang & 11 & 14 & 6 & 1 & 0 \\
\hline $20 \%-39 \%$ & Rendah & 6 & 1 & 0 & 0 & 0 \\
\hline $0 \%-19 \%$ & Sangat Rendah & 0 & 0 & 0 & 0 & 0 \\
\hline & Jumlah & 19 & 19 & 19 & 19 & 19 \\
\hline
\end{tabular}

Sumber : Hasil Observasi

Berdasarkan tabel dari data hasil analisis persentase observasi pelaksanaan teknik problem focused coping yang diperoleh maka dapat disimpulkan bahwa disetiap pertemuan terjadi peningkatan partisipasi siswa dalam mengikuti teknik problem focused coping. Meningkatnya partisipasi siswa dalam mengikuti kegiatan juga ikut mendukung terjadinya penurunan stress siswa dalam belajar matematika untuk kelompok eksperimen di SMP Negeri 1 Galesong Utara Kab. Takalar.

Gambaran tingkat stress belajar siswa pada pelajaran matematika di SMP Negeri 1 Galesong Utara Kab. Takalar pada kelompok kontrol. Berikut ini disajikan hasil data tingkat stress belajar siswa pada pelajaran matematika pada kelompok kontrol hasil pretest dan postest. 
Tabel 4.3 Data tingkat stress belajar siswa pada pelajaran matematika pada kelompok control sebelum (pretest) dan setelah (posttest).

\begin{tabular}{llcccc}
\hline \multirow{2}{*}{ Interval } & \multirow{2}{*}{ Kategori } & \multicolumn{4}{c}{ Kelompok Kontrol } \\
\cline { 3 - 6 } & & \multicolumn{3}{c}{ Pretest } & \multicolumn{2}{c}{ Posttest } \\
\cline { 3 - 6 } & & Frekuensi & Persentase & Frekuensi & Persentase \\
\hline $143-167$ & Sangat Tinggi & 4 & $21 \%$ & 3 & $15,7 \%$ \\
$118-142$ & Tinggi & 14 & $73,7 \%$ & 12 & $63,2 \%$ \\
$93-117$ & Sedang & 1 & $5,3 \%$ & 4 & $21 \%$ \\
$68-92$ & Rendah & 0 & $0 \%$ & 0 & $0 \%$ \\
$42-67$ & Sangat Rendah & 0 & $0 \%$ & 0 & 0 S $\%$ \\
& Jumlah & $\mathbf{1 9}$ & $\mathbf{1 0 0 \%}$ & $\mathbf{1 9}$ & $\mathbf{1 0 0 \%}$ \\
\hline
\end{tabular}

Sumber: Hasil Angket Kelompok Kontrol

Tingkat stress belajar siswa pada pelajaran matematika di SMP Negeri 1 Galesong Utara Kab. Takalar untuk kelompok kontrol, pada saat pre-test berada dalam ketegori sangat tinggi sebanyak 4 responden $(21 \%)$, kemudian kategori tinggi sebanyak 14 responden $(73,7 \%)$, dan pada ketegori sedang sebanyak 1 responden $(5,3 \%)$, Selanjutnya sesuai dengan nilai rata-rata skor yang diperoleh pada saat pre-test sebesar 130,1, dimana nilai rata-rata tersebut berada pada interval 118-142 yang berarti tinggi. Sedangkan pada saat post-test tingkat stress belajar siswa pada pelajaran matematika berada dalam kategori sangat tinggi 3 responden $(15,7 \%)$, kategori tinggi sebanyak 12 responden $(63,2 \%)$, kategori sedang sebanyak 4 responden $(21 \%)$, tidak ada siswa yang berada pada ketegori rendah dan sangat rendah pada saat pre-test maupun post-test. Adapun nilai rata-rata skor yang diperoleh pada saat post-test sebesar 122,4 dimana rata-rata tersebut berada pada interval 118-142 yang berarti tinggi. Dapat disimpulkan bahwa tingkat stress belajar siswa pada pelajaran matematika di SMP Negeri 1 Galesong Utara Kab. Takalar baik pada saat pretest maupun posttest untuk kelompok kontrol berada dalam ketegori tinggi.

Berdasarkan hasil perhitungan dengan menggunakan SPSS 20 for windows melalui paired sample t-test diperoleh data nilai t-test 12,814 dengan $\mathrm{df}=18$ dan nilai signifikan $(\mathrm{P})=$ $0,000<\alpha=0,05$. Berarti $\mathrm{H}_{0}$ ditolak dan $\mathrm{H}_{1}$ diterima yang artinya ada perbedaan nilai ratarata gain skor kelompok ekperimen dan kelompok control. Hal ini berarti bahwa hipotesis nihil (H0) yang berbunyi "Teknik Problem Focused Coping efektif dalam mengatasi stress belajar siswa pada pelajaran matematika di SMP Negeri 1 Galesong Utara Kab. Takalar" dinyatakan ditolak. Sehingga hipotesis kerja $\left(\mathrm{H}_{1}\right)$ yaitu "Teknik Problem
Focused Coping efektif dalam mengatasi stress belajar siswa pada pelajaran matematika di SMP Negeri 1 Galesong Utara Kab. Takalar" dinyatakan diterima. Maka dapat disimpulkan bahwa Teknik Problem Focused Coping efektif dalam mengatasi stress belajar siswa pada pelajaran matematika di SMP Negeri 1 Galesong Utara Kab. Takalar.

\section{SIMPULAN DAN SARAN}

Berdasarkan hasil penelitian mengenai efektivitas teknik Problem Focused Coping dalam mengatasi stres belajar siswa pada pelajaran matematika di SMP Negeri 1 Galut dapat disimpulkan bahwa: 1) Tingkat stres belajar siswa pada pelajaran matematika sebelum diberikan teknik Problem Focused Coping berada pada kategori tinggi kemudian mengalami penurunan setelah diberikan teknik Problem Focused Coping yaitu berada pada ketegori rendah. 2) Teknik Problem Focused Coping efektif dalam mengatasi stres belajar siswa pada pelajaran matematika di SMP Negeri 1 Galut.

Berdasarkan kesimpulan yang diambil, maka disarankan kepada: 1) Guru pembimbing, hendaknya menjadikan Teknik Problem Focused Coping sebagai salah satu alternatif pemberian bantuan dalam mengatasi stres belajar siswa pada pelajaran matematika. 2) Siswa hendaknya lebih bersedia dan lebih aktif dalam memanfaatkan fungsi bimbingan dan konseling di sekolah terutama layanan-layanan yang ada seperti teknik Problem Focused Coping untuk membantu dirinya menyelesaikan permasalahan yang dihadapinya. 3) Hasil penelitian ini terbatas padaa populasi dimana penelitian dilakukan sehingga penerapan pada ruang lingkup yang lebih luas dengan karakteristik yang berbeda kiranya perlu 
dilakukan penelitian lagi dengan menambah variabel-variabel penelitian dan memperluas ruang lingkup penelitian.

\section{DAFTAR RUJUKAN}

Abdullah, A. 2007. Mengatasi Stres pada Anak. Bandung: Kelompok Gramedia.

Arikunto. 2004. Prosedur Penelitian Suatu Pendekatan Praktik (Edisi Revisi). Jakarta: Rineka Cipta.

Armeli, S. 2001. Stressors, Appraisals, Coping and Post-Event Outcomes: The Dimensionality and Antecendents of Stress-Related Growth. Journal of Social and Clinical Psychology. Vol 20 No 3.

Amin, S.M. dan Al-Fandi, H. 2007. Kenapa Harus Stres Terai Stres Ala Islam. Jakarta: Sinar Grafika.

Bahtiar Ilham Muhammad. 2015. Efektivitas Strategi Problem Focused Coping \& Emotional Focused Coping dalam Meningkatkan Pengelolaan Stress Siswa di SMA Negeri 1 Barru. Jurnal of Guidance and Counseling. Vol. 5 No. 2.

Gerald C Davison, John M Nale, Ann M Kring. 2014. Psikologi Abnormal Edisi ke 9. Penerjemah Noermalasari Fajar. Jakarta: Rajawali Press.

Gunawati, R., Hartati, S., Listiara, A. 2006. Hubungan Antara Efektifitas Komunikasi Mahasiswa Dosen Pembimbing Utama Skripsi dengan Stres dalam Menyusun Skripsi Pada Mahasiswa Program Studi Psikologi Fakultas Kedokteran UNDIP. Jurnal Psikologi Universitas Diponegoro. Vol. 3 No. 2

Jeffrey S. Nevid. S, Beverly, G. 2002. Psikologi Abnormal. Jakarta: Erlangga.

Lazarus, R. S \& Folkman, S. 2006. Stress, Appraisal and Coping. New York. Springer.
Nawangsari, N. A. F. 2000. Kecemasan Siswa Pada Bidang Matematika di SLTP Surabaya (Laporan Penelitian Universitas Airlangga). Surabaya: Universitas Airlangga.

Sugiyono, 2012 . Metode Peneliian Kombinasi (Mixed Methods). Bandung: Alfabeta.

Taylor, S.E. dan Stanton, A.L. 2007. Coping Resources, Coping Proceses and Mental Health. The Annual Review of Clinical Psychology. 3:337 - 401 .

Rickard, J. 2000. Relaksasi untuk Anak-Anak. Jakarta: PT Grasindo.

Rizki, B.M., Kuncoro, J., Supradewi, R. 2008. Problem Focused Coping Pada Mahasiswa yang Hafidz ditinjau dari Kecerdasan Spiritual \& Jenis Kelamin. Jurnal Proyeksi. 3 (1). 70 - 80.

Rohmah, F.A. 2006. Pengaruh Diskusi Kelompok Untuk Menurunkan Stres Pada Mahasiswa yang Sedang Skripsi. Humanitas: Indonesian Psychological Journal Vol. 3 No. 11 Januari 2006.

Sari Indah Rani. 2013. Hubungan antara Hardness dengan Problem Focused Coping Pada Wanita karir.Jurnal Online Psikologi. Vol. 1 No. 2. 311 - 326.

Sugiyono. 2012. Metode Peneliian Kombinasi (Mixed Methods). Bandung: Alfabeta.

Taylor, S.E. dan Stanton, A.L. 2007. Coping Resources, Coping Proceses and Mental Health. The Annual Review of Clinical Psychology. 3:337 - 401 .

Wulandari, E. Theis, R. 2012. Pengaruh Problem Stres Matematika Sekolah Terhadap Hasil Belajar Matematika Siswa Kelas XI IPA SMAN 4 Jambi . Edumatika. Vol 02 Nomer 1 April. 2088-2157. 